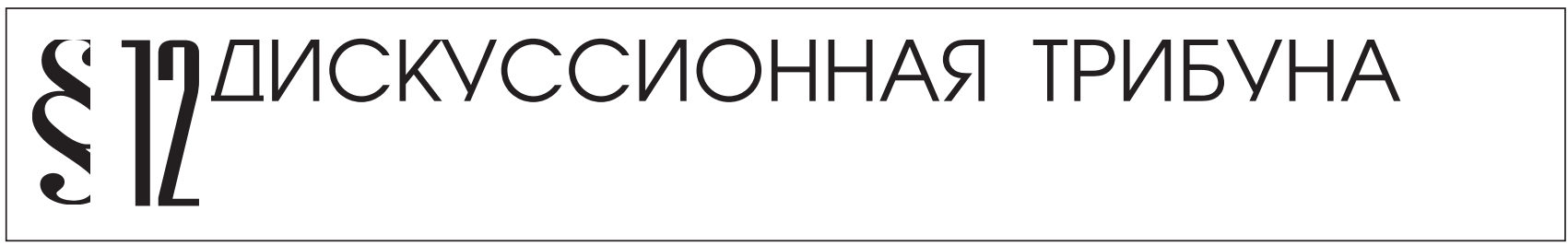

Осейчук В.И.

\title{
О МЕХАНИЗМЕ ФОРМИРОВАНИЯ ВЫСОКОПРОФЕССИОНАЛЬНОГО ВЫСШЕГО ЭШЕЛОНА ГОСУДАРСТВЕННОЙ ВЛАСТИ (В ПОРЯДКЕ НАУЧНОЙ ДИСКУССИИ)
}

Аннотация: Статья посвящена анализу механизма формирования высокопрофессиональной национальной элиты в сфере государственного управления. Особое внимание обращено на доминирование стихийных начал в рекрутировании высшей государственной бюрократии. Автором предложена система мер правового регулирования системы отбора, подготовки и продвижения лучших кадров в высший эшелон государственной власти. На взгляд автора, основные приниипы механизма формирования высшего эшелона государственной власти иелесообразно закрепить в Конституичи России. В статье поставлен вопрос о создании нового механизма формирования национальной элиты в сфере государственного управления. В исследовании использована система методов, в том числе: формально-юридический, диалектический, материалистический, системный, исторический, статистический, сочиологический. Если Россия намерена справиться с брошенныли ей вызовами, войти в число стран-лидеров, то ей предстоит создать новый механизм формирования национальной элиты в сфере государственного управления, в которую стремились бы попасть лучшие представители российского общества.речь идет о том, чтобы высший эшелон государственной власти страны представлял собой не простую сумму конкретных лиц, нередко в силу случая оказавшихся наделенными государственной властью, а социальную группу, которая формируется преимущественно в результате иеленаправленной селекции. Более того, наверху остаются лишь те, кто способен обеспечивать динамичное развитие страны и высокое качество жизни народа. Abstract: The article is devoted to the analysis of the mechanism for the formation of the highly professional national elite in the sphere of state administration. Special attention is paid to the domination of spontaneous elements in recruiting highest state bureaucracy. The author offers a system of measures for the legal regulation of the system of selection, training and promotion of the best cadres to the top echelon of the government power. In the opinion of the author the main principles of the mechanism for the formation of the higher echelon of state government should be provided for in the Constitution of the Russian Federation. The article raises an issue of the formation of the new mechanism for the formation of national elite in the sphere of state administration. The study involves a system of methods, including formal logical, dialectic, materialistic, systemic, historical, statistic, sociological. If Russia is going to deal with the challenge and become one of the leading states, it should form a new mechanism for the formation of the national elite in the sphere of state administration, so that the best representatives of the Russian society would strive to join it. The top echelon of state government of Russia should be more than just a sum of person, who came there sometimes by mere luck, rather it should be a social group, which is formed mostly by purposeful selection. Additionally, the only persons remaining in top echelon should be those, who are able to guarantee dynamic development of the state and high qualify of living standard for the people.

Ключевые слова: Народ, высшая государственная бюрократия, государственное управление, непрофессионализм, Конституция, стандарт профессиональных качеств, механизм отбора кадров, демократическое правовое государство, правящая партия, общественный прогресс.

Keywords: People, supreme state bureaucracy, state administration, unprofessionalism, Constitution, standard of professional qualities, mechanism for the cadres selection, democratic rule-of-law state, ruling party, social progress. 


\section{Право и политика $8(176) \cdot 2014$}

ема настоящей статьи практически не обсуждается в российском научном сообществе, а если и обсуждается, то крайне фрагментарно. Но непрофессионализм высшего эшелона государственной власти ${ }^{1}$ - это одна из главных проблем функционирования и развития сферы государственного управления страны. Более того, практика государственного управления Россией в постсоветский период испытывает настоящий голод по теоретическим построениям, касающимся путей формирования высокопрофессиональной высшей государственной бюрократии.

Очевидно, что в высшем эшелоне государственной власти современной России как воздух нужны кадры, обладающие широким кругозором, мудростью, бескорыстным служением отечеству, справедливостью, способностью рационально решать назревшие национальные проблемы. Ибо, как справедливо отмечал И. А. Ильин, «судьбы государств определяются качеством ведущего слоя: успехи государства суть его успехи; политические неудачи и беды народа свидетельствуют о его неудовлетворительности или прямо о его несостоятельности, - может быть, о его безволии, безыдейности, близорукости, а может быть, о его порочности и продажности. Такова судьба всех народов: они расплачиваются унижениями и страданиями за недостатки своего ведущего слоя»².

В этой связи обратим внимание то, что начало трансформации российского государства в постсоветский период показало полную теоретическую и практическую несостоятельность лидеров высшего эшелона государственной власти. У них не оказалось смелости и умений в принимаемых государственных решениях пойти вперед в преобразовании общественных отношений во благо российского народа. Они так и не поняли ограниченный характер социализма, как переходной ступени общественного прогресса. Более того, они не сумели в государственной политике принять те меры, которые двигали бы общество по пути развития свободы, справедливости, равенства и братства, всестороннего (физического, интеллектуального и духовного) развития человека, строительства демократического правового социального государства.

\footnotetext{
1 Под высшим эшелоном государственной власти в настоящей статье понимается круг лиц, замещающих государственные должности Российской Федерации, установленные Конституцией Российской Федерации, федеральными законами для непосредственного исполнения полномочий федеральных государственных органов и утвержденные Указом Президента Российской Федерации от 11 января 1995 г. № 32 «О государственных должностях Российской Федерации» (в ред. от 12.07.2012).

${ }^{2}$ Ильин И. А. О воспитании национальной элиты. М. 2001. С. 16.
}

Вместо движения вперед, основанного на сочетании в государственной политике достижений советского государства и лучших практик государственного управления стран-лидеров, политические лидеры России избрали стратегию разрушения прежних устоев и некритичного заимствования западного опыта. Например, достаточно быстро нашлись те политики, которые позвали российское общество назад - в капитализм. В частности, бывший вице-премьер российского правительства Е. Гайдар заявлял: «Смысл реформ предельно ясен: переход к рыночной, капиталистической экономике» ${ }^{3}$. Таким политикам представлялось, что капитализм сам установит по рыночным законам порядок в стране и создаст изобилие. Однако, финансово-экономический кризис современной капиталистической системы с блеском показывает интеллектуальную и политическую ограниченность либеральных реформаторов.

Непрофессионализм высшей государственной бюрократии постсоветской России проявился и в том, что она оказалась интеллектуально и политически слабее своих зарубежных конкурентов. По своей наивности или глупости многие ее представители думали, что Запад поможет России строить новое государство. Поэтому, как отмечает видный американский историк Стивен Коэн, «толпы американских политических миссионеров, обычно именуемых «советниками», наводнили Россию в первой половине 90-х гг. Спонсируемые американским правительством, идеологическими организациями, разными фондами и институтами, они проникали всюду, где существовал материал для «новообращения», - от политических движений, профсоюзов, средств массовой информации и школ до офисов самого российского правительства. Среди прочих миссионерских деяний американцев было финансирование нужных российских политиков, инструктаж министров, составление проектов законов и указов президента, написание новых учебников и перевыборы президента Ельцина в 1996 г.»${ }^{4}$. Такими методами американцы «околпачивали» Россию и не только ее.

О непрофессионализме многих представителей высшей государственной бюрократии России говорит и такой факт. Когда во время своего визита в Москву бывший президент США Никсон попросил действующего министра иностранных дел А. Козырева очертить реальные интересы новой России, тот сказал:

\footnotetext{
${ }^{3}$ Гайдар Е. Уроки Октября // Комсомольская правда. 1994. 29 сентября.

${ }^{4}$ Коэн С. Провал Крестового похода. США и трагедия посткоммунистической России. М., 2001.С. 23.
} 
«Вы знаете, господин президент, что одна из проблем Советского Союза состояла в том, что мы слишком как бы заклинились на национальных интересах. И теперь мы больше думаем об общечеловеческих ценностях». Позднее, комментируя эти слова, Никсон заметил: «Когда я был вице-президентом, а затем президентом, я хотел, чтобы все знали, что я «сукин сын» и во имя американских интересов буду драться изо всех сил. Киссинджер был такой «сукин сын», что я еще могу у него поучиться. А этот, - продолжал Никсон, - когда Советский Союз только что распался, когда новую Россию нужно защищать, этот хочет показать, какой он приятный человек»5.

Одним из первых, кто обратил должное внимание на проблему механизма ${ }^{6}$ отбора лучших россиян в высший эшелон государственной власти в постсоветский период, был великий русский философ И. А. Ильин. Он отмечал: «мы знаем и понимаем, в чем будет состоять основная задача русского национального спасения и строительства после революции: она будет состоять в выделении к верху лучших людей, - людей, преданных России, национально чувствующих, государственно мыслящих, волевых, идейно-творческих, несущих народу не месть и не распад, а дух освобождения, справедливости и сверхклассового единения. Если отбор этих новых русских людей удастся и совершится быстро, то Россия восстановится и возродится в течение нескольких лет; если же нет, - то Россия перейдет из революционных бедствий в долгий период послереволюционной деморализации, всяческого распада и международной зависимости» 7 .

Надо честно признать, что к настоящему времени эффективный и прозрачный механизм выдвижения лучших россиян в высший эшелон государственной власти создать не удалось. Как показывает практика, высший эшелон государственной власти постсоветской России во многом формируется стихийно. Отсутствие эффективных и прозрачных механизмов отбора лучших россиян в высший эшелон государственной власти ведет к тому, что среди высшей государственной бюрократии доминируют карьеристы и дилетанты. Но, как справедливо отмечает Деметрадзе М. Р, «неподготовленные к переменам индивиды не могут создавать современное

${ }_{5}^{5}$ Примаков Е. М. Встречи на перекрестках. Екатеринбург, 2004. C. 195.

${ }^{6}$ Под механизмом понимается совокупность форм, способов, средств, приемов, порядка, закрепленных в правовых актах и используемых в государственной кадровой политике с целью обеспечения профессионализма высшего эшелона государственной власти.

${ }^{7}$ Ильин И. А. О воспитании национальной элиты. М. 2001. С. 16. государство, а непрофессиональные политики - управлять сложными динамичными процессами» ${ }^{8}$.

Хотя в высшем эшелоне государственной власти страны имеются и профессионалы, но не они определяют государственную политику. Ибо непрофессионалы высшего эшелона государственной власти - это «творцы «кадровой серости», под стать себе они подбирают «серость», гасят, гробят потенциал других или «жируют» за счет интеллектуальных и профессиональных способностей своих «гибких» подчиненных, ибо профессионалы, которые в ладах с нравственностью, люди с высоким чувством собственного достоинства, стараются держаться от них подальше. ... При этом персональной ответственности у руководителя за подобное окружение - практически никакой» ${ }^{9}$.

Более того, непрофессионализм высшего эшелона государственной власти ведет к тому, что решение важнейших национальных проблем «подменяется созданием колоссального госаппарата, поглощенного решением внутренних проблем, а обеспечение сохранения народонаселения путем достижения достойного уровня и качества жизни граждан на всей территории страны трансформируется в создание все новых проблем для этих граждан» ${ }^{10}$.

Результатом непрофессионализма высшего эшелона государственной власти «стала практическая деградация целых отраслей народного хозяйства (промышленность, наука, сельское хозяйство, образование, здравоохранение, ВПК). Особенно тяжелое положение сложилось в промышленности, где основные производственные фонды изношены на 70-80\%, утрачены высококвалифицированные кадры, отсутствуют инновационные разработки» ${ }^{11}$.

Непрофессионализм высшего эшелона государственной власти - не только в прошлом. К сожалению, и сегодня многие государственные решения, касающиеся модернизации страны, не отвечают остроте ситуации, потребностям и интересам большинства россиян, и прежде всего молодежи. Скорее всего, в этом кроется

\footnotetext{
${ }^{8}$ Деметрадзе М. Р. Проблемы несоответствия социокультурной политики России процессам глобальной модернизации // Право и политика. 2014. № 1. С. 24.

${ }^{9}$ Турчинов А. Кадровая безопасность России: постановка проблемы // Государственная служба. 2010. № 4. С. 19-20

${ }^{10}$ Добрынин Н. М. Краткий очерк о судьбе российского конституционализма: о сущности, эволюции и неотложности конституционной реформы // Право и политика. 2013. № 12. с. 1748.

${ }^{11}$ Богачев $B$. «Ручное» управление как принцип действия новых российских топ-менеджеров // Проблемы теории и практики управления. 2013. № 8. С. 17.
} 


\section{Право и политика $8(176) \cdot 2014$}

основная причина затухания темпов роста национального ВВП. Как известно, пороговым значением для современной России является ежегодный рост ВВП на 6-7\%, что необходимо для решения долгосрочных задач социального развития, модернизации отечественной экономики и обеспечения национальной безопасности. Однако, последнее пятилетие наблюдалась иная динамика ВВП: 2009 г. - минус 7,9\%; 2010 г. - плюс 4\%; 2011 г. - 4,1\%; 2012 г. - плюс 3,4\%; 2013г. - 1,5\%; $2014-0 \%$ (прогноз).

Анализ практики государственного управления стран-лидеров показывает, что в их государственной кадровой политике акцент смещен в сторону создания эффективных механизмов подготовки, отбора и продвижения профессионалов, а также признания важной роли нравственной безупречности кандидатов на высшие государственные должности. В этой связи А. Турчинов с сожалением отмечает, что «в отечественном публичном управлении о таких тенденциях, а тем более механизмах приходится только мечтать...» ${ }^{12}$. Но если не мечтать, то теряется смысл практической и теоретической деятельности. Поэтому отечественным теоретикам и практикам государственного управления обязательно надо мечтать.

Очевидно, что в современных условиях, когда требуется вывод страны на новые рубежи развития, процессы формирования высшего эшелона государственной власти могут и должны быть стимулированы государственным механизмом регуляции. Речь идет о создании политико-правового, организационного и финансово-экономического механизмов отбора и продвижения в высший эшелон государственной власти лучших россиян, - людей обладающих необходимыми профессиональными знаниями, способностями решать назревшие национальные проблемы и соответствующих высоким моральным стандартам (готовых подчинить личный интерес общественному интересу, не врущих, не ворующих и т.п.). По большому счету речь идет о людях способных превратить страну в высокоразвитое демократическое правовое социальное государство и сообщество людей, поражающее мир своим гуманным и рациональным жизнеустройством и образом жизни.

Формирование высокопрофессионального корпуса высшего эшелона государственной власти, автор считает одной из важнейших задач современной России. Без национальной элиты в сфере государственного

12 Турчинов А. Кадровая безопасность России: постановка проблемы // Государственная служба. 2010. № 4. С. 19-20 управления призыв сделать страну одним из лидеров мирового сообщества, обеспечить высокое качество жизни народа останутся пустыми призывами и мечтаниями. Поэтому нужны конкретные меры по формирования национально ориентированной элиты в сфере государственного управления, а не ожидание, когда она вырастет стихийно, или объявлять элитой в сфере государственного управления тех, кто ею на деле не является.

На взгляд автора, для формирования национальной элиты в сфере государственного управления требуется принятие комплекса политических, правовых, организационных и финансово-экономических мер.

Во-первых, необходимо законодательно закрепить стандарт профессиональных знаний, деловых и морально-нравственных качеств, необходимых для занятия должности в высшем эшелоне государственной власти.

Во-вторых, требуется законодательно ограничить численность высшего эшелона государственной власти и расходов на его содержание. Например, в США численность Службы высших руководителей законодательно ограничена числом 10777 человек. По некоторым оценкам, сегодня на содержание госаппарата в России тратится средств в два раза больше, чем в США. И это при том, что наше население значительно меньше, чем в США (143 млн. против 315 млн.), а американский ВВП в 7 раз больше нашего ${ }^{13}$.

B-третьих, важно законодательно закрепить конкурсный порядок назначения на должности в высшем эшелоне государственной власти, включающий сдачу сложного экзамена по теории и практике государственного управления, прохождения психологического тестирования на предмет выявления качеств, необходимых для замещения должности.

Представляется, что основные принципы механизма формирования высшего эшелона государственной власти целесообразно закрепить в Конституции России. Как известно, одно из главных назначений всякой Конституции - обеспечить конституционно-правовой механизм прихода в органы государственной власти и местного самоуправления наиболее умелых, знающих, добросовестных и ответственных людей. На взгляд автора настоящей статьи, Конституция страны должна содержать следующую норму: Граждане Российской Федерации имеют равный доступ к государственной и муниципальной службе в соответствии с профессиональными знаниями, деловыми и морально-нрав-

\footnotetext{
${ }^{13}$ Костиков В. Кто держит Бога за бороду // Аргументы и факты. 2013. № 43
} 
ственными качествами. Отбор лучших кандидатов на должности государственной и муниципальной службы осуществляется, как правило, на основе открытых конкурсов, сложных экзаменов и психологических тестов, проводимых независимыми центрами оценки. Руководители органов государственной власти и местного самоуправления несут персональную ответственность за нарушение принципа преимущественно конкурсного отбора лучших кандидатов на должности государственной и муниципальной службы.

В-четвертых, целесообразно требовать от кандидатов на должности в высшем эшелоне государственной власти доказательств участия в разработке и реализации крупных проектов, например, возрождения регионов России или освоении Сибири и Дальнего Востока, восстановлении промышленности и сельского хозяйства и т.п.

Кстати, разработка и реализация крупных национальных проектов создаст дополнительные условия для выращивания государственных фигур из молодежной среды. Сегодня талантливая молодёжь очень неохотно идёт на государственную и муниципальную службу, а если и идет, то долго там, как правило, не задерживается. Потому что, во-первых, нет крупных национальных проектов, а значит, нет возможности проявить себя. Вовторых, когда отсутствуют крупные национальные проекты, то на государственной и муниципальной службе процветает мелкое политиканство, делячество и пиар.

В-пятых, необходимо учитывать гражданские позиции кандидатов на должности в высшем эшелоне государственной власти по актуальным вопросам государственного управления, например, как обеспечить оплату труда и пенсии, соответствующих международным стандартам и достижениям стран-лидеров, как повысить производительность труда в промышленности и сельском хозяйстве и т.п.

B-шестых, следует учитывать предложения кандидатов на должности в высшем эшелоне государственной власти по созданию новой модели государственного управления, ориентированной на потребности и интересы большинства народа.

В-седьмых, целесообразно ограничить двумя сроками пребывание на одной должности в высшем эшелоне государственной власти. О том какую пользу эта мера может принести стане, показывает опыт современного Китая, где генеральный секретарь компартии вправе занимать эту должность только два срока.

В-восьмых, важно привязать вознаграждение представителей высшего эшелона государственной власти к средней или минимальной заработной плате в стране, например, не более 20 минимальных зарплат. Возможно, в этом случае минимальный размер оплаты труда не будет столь унизительным, как сейчас. При этом следует преодолеть порочную практику, когда предпочитают сравнивать зарплату высшего эшелона государственной власти России с оплатой труда на ключевых должностях в частном секторе или с окладами чиновников в развитых странах, но не с минимальной или средней зарплатой граждан, как это принято делать в развитых странах. На практике это привело к тому, что, например, зарплата депутата Государственной Думы России примерно в 14 раз, а Президента страны в 24 раза выше средней зарплаты по стране. Не лучше ситуация на региональном и муниципальном уровнях. Для сравнения: президент США и канцлер Германии получают ежемесячное вознаграждение в 7-8 раз выше средней зарплаты граждан страны. Как известно, в СССР зарплата Генерального секретаря ЦК КПСС была в 6 раз выше средней зарплаты по стране.

По подсчетам аудиторско-консалтинговой компании ФБК, ВВП в России с 2001 по 2010 г вырос в 1,6 раза. При этом зарплаты чиновников за период с 2000 по 2012 г. возросли в 25,4 раза: с 2276,2руб. до 57900 руб. Значит, зарплата чиновников росла в 15,8 раза быстрее, чем ВВП ${ }^{14}$.

В-девятых, необходимо устранить административные барьеры для постоянного выдвижения народом все более достойных людей и обновления ими старого состава высшей государственной бюрократии. Подобная мера необходима и потому что те, кто попадают на должности в высшем эшелоне государственной власти, стремятся в нем закрепиться и препятствуют притоку «свежей крови». Это консервирует ситуацию в высшем эшелоне государственной власти, усиливает в нем бюрократизм и коррупцию.

B-десятых, следует тщательно отбирать кандидатов для направления за границу в целях изучения лучших практик государственного управления странлидеров. В этой связи следует вспомнить отечественную историю о том, что проект Петра I по заимствованию европейских образцов жизни потребовал направления многих молодых людей в Европу. После возвращения они образовали новую национальную элиту. Подобный подход использовал и Сталин с инженерами, которые потом становились главными конструкторами и «командирами производства». Они сначала перенимали

\footnotetext{
${ }^{14}$ Сибирцев В. А. Система оплаты работников государственных и муниципальных учреждений по полезности результатов их труда // Юридический мир. 2013. № 7. С. 19.
} 


\section{Право и политика $8(176) \cdot 2014$}

опыт в США и Германии, потом уезжали в Сибирь и на Дальний Восток строить там новые заводы и затем возвращались в Москву представителями национальной элиты в сфере государственного управления.

В-одиннадцатых, требуется ограничить концентрацию власти в одном органе или в одних руках. В противном случае демократические институты являются пустой формальностью, реальная власть все больше концентрируется на вершине пирамиды, а большинство представителей высшей государственной бюрократии превращаются в простых статистов, от которых мало, что зависит.

В двенадцатых, целесообразно провести масштабную чистку высшего эшелона государственной власти силами независимых центров оценки на основе следующих критериев: профессиональные знания, деловые и морально-нравственные качества. Иным способом существенно обновить высший эшелон государственной власти страны невозможно. Это необходимо сделать и потому что, как справедливо отмечает Президент России В. В. Путин, «сегодняшний госаппарат является в значительной степени забюрократизированной, коррумпированной системой, не мотивированной на позитивные изменения, а тем более на динамичное развитие» ${ }^{15}$.

При этом отбор новых кадров в высший эшелон государственной власти должен происходить в первую очередь из высококвалифицированных представителей научного и экспертного сообщества, не интегрированного в жизнь действующего чиновничьего аппарата. Предыдущий провал попыток кадрового обновления высшей государственной бюрократии в начале 1990-х годов был связан именно с тем, что отобранные в ее среду кадры - ученые и эксперты - не создали критической массы и были либо поглощены забюрократизированной и коррумпированной системой, либо отторгнуты ею.

Только приход в высший эшелон государственной власти умных, деловых и нравственных людей, ставящих превыше всего национальные интересы, позволит оздоровить морально-политическую и социально-экономическую ситуацию в российском государстве. Им же предстоит освободить государственный аппарат от тех, кто ради собственных интересов отодвигает на второй план интересы российского народа.

В-тринадцатых, необходимо оптимально сочетать опытные и молодые кадры в высшем эшелоне государственной власти. Причем при омоложении кадрового состава высшей государственной бюрократии особое значение имеет работа независимых и авторитетных конкурсных комиссий. Если таковые отсутствуют,

${ }^{15}$ Российская газета. 2008. 9 февраля. то административно-финансовые группировки под фанфары об омоложении высшей государственной бюрократии протаскивают своих представителей. Не меньшую опасность представляет и рекрутирование в высший эшелон государственной власти беспринципных молодых людей, готовых ради карьеры на все.

B-четырнадцатых, требуется законодательно закрепить принцип персональной ответственности министров перед российским народом за результаты своей деятельности либо бездеятельность на порученном им участке государственной деятельности. При этом любой министр должен иметь четкие представления о том, за какие показатели развития страны или «провалы» во вверенном ему ведомстве он несет персональную ответственность. Кроме того, принцип персональной ответственности призван «сковывать, удерживать власть от произвола и силовых рефлексов, ибо она (власть) имеет тенденцию к выходу из под всякого контроля, юридических ограничений, связанности, подчинения определенным правилам» ${ }^{16}$.

Общеизвестно, что высший эшелон государственной власти во многом формируется правящей партией. Однако, на определенном этапе своего развития правящая партия перестает играть роль инициатора и организатора прогрессивных изменений в общественных отношениях, превращается в тормоз общественного развития и наступает время для смены политических лидеров. Поэтому общество обязано заблаговременно позаботиться о механизме смены правящей партии. Естественно, механизм смены правящей партии должны быть в первую очередь правовым, а не силовым. Это наиболее рациональных подход в решении политических кризисов.

В-пятнадцатых, целесообразно законодательно закрепить механизм ежегодной оценки результатов деятельности высшего эшелона государственной власти законодательными органами государственной власти или независимыми центрами оценки.

В шестнадцатых, пора создать федеральный орган по управлению государственной службой (разговоры на эту тему ведутся с 1995г.), который призван создать систему конкурсного отбора кандидатов в высшее звено государственной службы, соответствующих возросшим требованиям народа, а также подготовки кадров для замещения высших государственных должностей в специализированных образовательных учреждениях федерального и регионального уровней.

${ }^{16}$ Матузов Н. И. Право и политика: антиподы или союзники? // Право и политика. 2014. № 5. С. 580-581. 
Возрождение России, обеспечение лидерства России в развитии экономики и качестве жизни народа невозможно без высокопрофессионального высшего эшелона государственной власти. Но возрождение страны - это прорыв в будущее, когда страна не испытывает глупостей и провалов политики высших органов государственной власти, а нанятый страной высший эшелон государственной бюрократии квалифицированно решает назревшие национальные проблемы.

Для того чтобы высший эшелон государственной власти был способен к формулировке и реализации стратегических ориентиров и базовых идеологических ценностей страны, механизм отбора лучших россиян в элиту государственного управления должен ориентировать кандидатов на постоянную работу над собой для того, чтобы отвечать следующим требованиям. Во-первых, высший эшелон государственной власти обязан быть способным осуществлять постоянный и системный анализ происходящего в стране в целом и ее регионах, производить объективную оценку текущей ситуации с точки зрения базовых идеологических ценностей и исторических перспектив России. Во-вторых, для того чтобы высший эшелон государственной власти был способен действительно осуществлять связь и взаимодействие органов государственной власти и институтами гражданского общества, он должна быть национальным и привязанным к судьбе России и ее народа. В него должны входить те, кто доказал результатами своей жизни и деятельности, что обустраивают жизнь в своей стране. Те чиновники, которые не обустраивают свою жизнь в России, в высшем эшелоне государственной власти служить не должны. В-третьих, высший эшелон государственной власти обязан предоставлять обществу долгосрочную стратегию социально-экономического развития страны лет на 20-25, которая должна утверждаться на общенациональном референдуме. Если эта стратегия не получает поддержки на общенациональном референдуме, то ее авторы должны уходить в отставку. Президент России, который меняется через каждые четыре или шесть лет, может и доложен формулировать цели своей деятельности в рамках этой стратегии и только в пределах срока своих полномочий. Он вправе также инициировать проведение общенационального референдума по корректировке долгосрочной стратегии социальноэкономического развития страны.

Если мы не начнем широкую общественную дискуссию относительно уровня профессионализма высшего эшелона государственной власти и механизма формирования национальной элиты в сфере государ- ственного управления, то Россия как великая страна и один из мировых центров силы не состоится.

Если Россия намерена справиться с брошенными ей вызовами, войти в число стран-лидеров, то ей предстоит создать новый механизм формирования национальной элиты в сфере государственного управления, в которую стремились бы попасть лучшие представители российского общества. А для этого в первую очередь необходимо «развитие беспристрастной и эффективной государственной службы, в рамках которой прием на работу и продвижение по службе основывается на системе личных достоинств» ${ }^{17}$.

Следовательно, речь идет о том, чтобы высший эшелон государственной власти страны представлял собой не простую сумму конкретных лиц, нередко в силу случая оказавшихся наделенными государственной властью, а социальную группу, которая формируется преимущественно в результате целенаправленной селекции. Более того, наверху остаются лишь те, кто способен обеспечивать динамичное развитие страны и высокое качество жизни народа.

И последнее. Автор осознает, что шансов на реализацию мер, предлагаемых в настоящей статье, пока немного, ибо высшая государственная власть их, как правило, отторгает. Но российское научное сообщество во взаимодействии с теми, кто мечтает стать новыми лидерами современной России, обязано обсуждать меры обеспечения профессионализма высшего эшелона государственной власти и завоевывать общественное сознание для их реализации в недалеком будущем.

\section{Библиография:}

1. Богачев В. «Ручное» управление как принцип действия новых российских топ-менеджеров // Проблемы теории и практики управления. 2013. № 8 .

2. Деметрадзе М. Р. Проблемы несоответствия социокультурной политики России процессам глобальной модернизации // Право и политика. 2014. № 1.

3. Добрынин Н. М. Краткий очерк о судьбе российского конституционализма: о сущности, эволюции и неотложности конституционной реформы // Право и политика. 2013. № 12.

4. Ильин И. А. О воспитании национальной элиты. M. 2001.

\footnotetext{
${ }^{17}$ Международные акты о правах человека. Сборник документов. M., 2000. C. 660.
} 


\section{Право и политика $8(176) \cdot 2014$}

5. Коэн С. Провал Крестового похода. США и трагедия посткоммунистической России. М., 2001.

6. Матузов Н. И. Право и политика: антиподы или союзники? // Право и политика. 2014. № 5.

7. Международные акты о правах человека. Сборник документов. М., 2000.

8. Примаков Е. М. Встречи на перекрестках. Екатеринбург, 2004.

9. Турчинов А. Кадровая безопасность России: постановка проблемы // Государственная служба. 2010. № 4.

10. Сибирцев В. А. Система оплаты работников государственных и муниципальных учреждений по полезности результатов их труда // Юридический мир. 2013. № 7.

11. Ф. К. Есиева Эволюция высших органов государственной власти на завершающем этапе развития советской государственности // Политика и Общество. - 2012. - 2. - С. 13-18.

12. Тихомиров Ю.А. Конституционные модели государств в контексте общественного развития // Журнал зарубежного законодательства и сравнительного правоведения. - 2013. - 6. - С. 1000-1005.

13. Борисенков А.А. Современная российская конституция о власти // NB: Вопросы права и политики. - 2014. - 1. - C. 19-44. DOI: 10.7256/23059699.2014.1.10585. URL: http://www.e-notabene.ru/lr/ article_10585.html

14. Борисенков А.А. Политическая власть - политическая субстанция // NB: Проблемы общества и политики. - 2013. - № 6. - C.193-217. DOI: 10.7256/23060158.2013.6.806. URL: http://e-notabene.ru/pr/ article_806.html

15. Самарская Е.А. Технократическая власть и судьбы демократии // NB: Философские исследования. - 2013. - № 6. - C.590-624. DOI: 10.7256/23060174.2013.6.605. URL: http://e-notabene.ru/fr/ article_605.html

16. Локтионов М.В.. Модернистское и постмодернистское понимание власти. // Философия и культура. - 2014. - № 5. - C. 104-107. DOI: 10.7256/19992793.2014.5.11750

17. А. В. Герасимов. Проблемы эффективного использования человеческого потенциала в современных условиях // Политика и Общество. - 2011. - № 11. - C. 104-107.

18. Д.С. Коновалова. Психологическая устойчивость современных управленцев. // Психология и Психотехника. - 2011. - № 2. - С. 104-107.

19. Нарутто С.В.. Правовая основа противодействия коррупции: от истории к современности
// Национальная безопасность / nota bene. 2013. - № 5. - C. 104-107. DOI: 10.7256/20738560.2013.5.9072

20. Комахин Б.Н.. К вопросу об определении критериев эффективности административно-правового регулирования публично-служебных отношений в контексте модернизации государственного управления и инновационного развития // Полицейская деятельность. - 2013. - № 4. - С. 104-107. DOI: 10.7256/2222-1964.2013.4.9452

21. Мапельман В.М.. Госслужащие в Российской Федерации // Политика и Общество. - 2013. - № 6. C. 104-107. DOI: $10.7256 / 1812-8696.2013 .6 .8096$

22. Лаврентьева О.О.. К вопросу о совершенствовании информационного обеспечения государственной гражданской службы в контексте ее модернизации и противодействия коррупции // Полицейская деятельность. - 2012. - № 4. - С. 104-107. Ватель А.Ю.. Административные и этические стандарты в системе государственной службы зарубежных государств // Полицейская деятельность. - 2012. № 2. - С. 104-107

23. Ф. К. Есиева Эволюция высших органов государственной власти на завершающем этапе развития советской государственности // Политика и Общество. - 2012. - 2. - С. $13-18$.

24. Долгих И.П., Черняев Г.М. О юридической стороне национального вопроса // NB: Вопросы права и политики. - 2014. - 1. - C. 45 - 53. DOI: 10.7256/23059699.2014.1.10788. URL: http://www.e-notabene.ru/ lr/article_10788.html

25. А.В. Безруков Роль Президента России в механизме реализации конституционных принципов федерализма, единства государственной власти и разделения властей // Политика и Общество. - 2013. -3. - C. 263 -269. DOI: 10.7256/1812-8696.2013.03.2.

\section{References (transliteration):}

1. Bogachev V. «Ruchnoe» upravlenie kak printsip deistviya novykh rossiiskikh top-menedzherov // Problemy teorii i praktiki upravleniya. 2013. № 8 .

2. Demetradze M. R. Problemy nesootvetstviya sotsiokul'turnoi politiki Rossii protsessam global'noi modernizatsii // Pravo i politika. 2014. № 1.

3. Dobrynin N. M. Kratkii ocherk o sud'be rossiiskogo konstitutsionalizma: o sushchnosti, evolyutsii i neotlozhnosti konstitutsionnoi reformy // Pravo i politika. 2013. № 12. 
DOI: $10.7256 / 1811-9018.2014 .8 .12690$

При цитировании этой статьи сноска на doi обязательна

Дискуссионная трибуна

4. Il'in I. A. O vospitanii natsional'noi elity. M. 2001.

5. Koen S. Proval Krestovogo pokhoda. SShA i tragediya postkommunisticheskoi Rossii. M., 2001.

6. Matuzov N. I. Pravo i politika: antipody ili soyuzniki? // Pravo i politika. 2014. № 5.

7. Primakov E. M. Vstrechi na perekrestkakh. Ekaterinburg, 2004.

8. Turchinov A. Kadrovaya bezopasnost' Rossii: postanovka problemy // Gosudarstvennaya sluzhba. 2010. № 4.

9. Sibirtsev V. A. Sistema oplaty rabotnikov gosudarstvennykh i munitsipal'nykh uchrezhdenii po poleznosti rezul'tatov ikh truda // Yuridicheskii mir. 2013. № 7.

10. F. K. Esieva Evolyutsiya vysshikh organov gosudarstvennoi vlasti na zavershayushchem etape razvitiya sovetskoi gosudarstvennosti // Politika i Obshchestvo. - 2012. - 2. - C. 13-18.

11. Tikhomirov Yu.A. Konstitutsionnye modeli gosudarstv v kontekste obshchestvennogo razvitiya // Zhurnal zarubezhnogo zakonodatel'stva i sravnitel'nogo pravovedeniya. - 2013. - 6. - C. 1000-1005.

12. Borisenkov A.A. Sovremennaya rossiiskaya konstitutsiya o vlasti // NB: Voprosy prava i politiki. - 2014. -1. - C. 19-44. DOI: 10.7256/2305-9699.2014.1.10585.

URL: http://www.e-notabene.ru/lr/article_10585.html

13. Borisenkov A.A. Politicheskaya vlast' - politicheskaya substantsiya//NB: Problemy obshchestva i politiki.-2013. - № 6. - S.193-217. DOI: 10.7256/2306-0158.2013.6.806. URL: http://e-notabene.ru/pr/article_806.html

14. Samarskaya E.A. Tekhnokraticheskaya vlast' i sud'by demokratii // NB: Filosofskie issledovaniya. - 2013. № 6. - S.590-624. DOI: 10.7256/2306-0174.2013.6.605. URL: http://e-notabene.ru/fr/article $605 . \mathrm{html}$

15. Loktionov M.V.. Modernistskoe i postmodernistskoe ponimanie vlasti. // Filosofiya i kul'tura. - 2014. - № 5. - S. 104-107. DOI: 10.7256/1999-2793.2014.5.11750

16. A. V. Gerasimov. Problemy effektivnogo ispol'zovaniya chelovecheskogo potentsiala v sovremennykh usloviyakh // Politika i Obshchestvo. - 2011. - № 11. - S. 104-107.
17. D.S. Konovalova. Psikhologicheskaya ustoichivost' sovremennykh upravlentsev. // Psikhologiya i Psikhotekhnika. - 2011. - № 2. - S. 104-107.

18. Narutto S.V.. Pravovaya osnova protivodeistviya korruptsii: ot istorii k sovremennosti // Natsional'naya bezopasnost' / nota bene. - 2013. - № 5. - S. 104-107. DOI: $10.7256 / 2073-8560.2013 .5 .9072$

19. Komakhin B.N.. K voprosu ob opredelenii kriteriev effektivnosti administrativno-pravovogo regulirovaniya publichno-sluzhebnykh otnoshenii v kontekste modernizatsii gosudarstvennogo upravleniya i innovatsionnogo razvitiya // Politseiskaya deyatel'nost'. - 2013. № 4. - S. 104-107. DOI: 10.7256/2222-1964.2013.4.9452

20. Mapel'man V.M.. Gossluzhashchie v Rossiiskoi Federatsii // Politika i Obshchestvo. - 2013. - № 6. - S. 104-107. DOI: 10.7256/1812-8696.2013.6.8096

21. Lavrent'eva O.O.. K voprosu o sovershenstvovanii informatsionnogo obespecheniya gosudarstvennoi grazhdanskoi sluzhby $\mathrm{v}$ kontekste ee modernizatsii i protivodeistviya korruptsii // Politseiskaya deyatel'nost'. - 2012. - № 4. - S. 104-107. Vatel' A.Yu.. Administrativnye i eticheskie standarty v sisteme gosudarstvennoi sluzhby zarubezhnykh gosudarstv // Politseiskaya deyatel'nost'. - 2012. - № 2. - S. 104-107

22. F. K. Esieva Evolyutsiya vysshikh organov gosudarstvennoi vlasti na zavershayushchem etape razvitiya sovetskoi gosudarstvennosti // Politika i Obshchestvo. - 2012. - 2. - C. 13 - 18 .

23. Dolgikh I.P., Chernyaev G.M. O yuridicheskoi storone natsional'nogo voprosa // NB: Voprosy prava i politiki. - 2014. - 1. - C. 45 - 53. DOI: 10.7256/23059699.2014.1.10788. URL: http://www.e-notabene.ru/ 1r/article_10788.html

24. A.V. Bezrukov Rol' Prezidenta Rossii v mekhanizme realizatsii konstitutsionnykh printsipov federalizma, edinstva gosudarstvennoi vlasti i razdeleniya vlastei // Politika i Obshchestvo. - 2013. - 3. - C. 263 - 269. DOI: 10.7256/1812-8696.2013.03.2. 